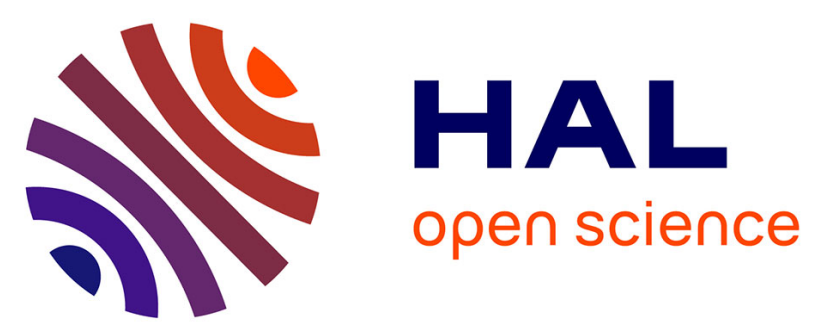

\title{
Influence of the normal load of scratching on cracking and mechanical strength of soda-lime-silica glass
}

Nasreddine Bensaid, Saci Benbahouche, Fouad Roumili, Jean-Christophe Sangleboeuf, Jean-Benoit Le Cam, Tanguy Rouxel

\section{- To cite this version:}

Nasreddine Bensaid, Saci Benbahouche, Fouad Roumili, Jean-Christophe Sangleboeuf, JeanBenoit Le Cam, et al.. Influence of the normal load of scratching on cracking and mechanical strength of soda-lime-silica glass. Journal of Non-Crystalline Solids, 2018, 483, pp.65-69. 10.1016/j.jnoncrysol.2018.01.004 . hal-01713404v2

HAL Id: hal-01713404

https://hal-univ-rennes1.archives-ouvertes.fr/hal-01713404v2

Submitted on 25 May 2018

HAL is a multi-disciplinary open access archive for the deposit and dissemination of scientific research documents, whether they are published or not. The documents may come from teaching and research institutions in France or abroad, or from public or private research centers.
L'archive ouverte pluridisciplinaire HAL, est destinée au dépôt et à la diffusion de documents scientifiques de niveau recherche, publiés ou non, émanant des établissements d'enseignement et de recherche français ou étrangers, des laboratoires publics ou privés.

\section{(c)(1)}

Distributed under a Creative Commons Attribution| 4.0 International License 


\title{
Influence of the normal load of scratching on cracking and mechanical strength of soda-lime-silica glass.
}

\author{
Nasreddine BENSAID ${ }^{(1)}$, Saci BENBAHOUCHE ${ }^{(1)}$, Fouad ROUMILI ${ }^{(1)}$, \\ Jean-Christophe SANGLEBOEUF ${ }^{(2)}$, Jean-Benoît LE CAM ${ }^{(2)}$, Tanguy ROUXEL ${ }^{(2)}$ \\ (1) Laboratoire de Mécanique de Précision Appliquée - Institut d'Optique et Mécanique de Précision - \\ Université Ferhat ABBAS, Sétif 1, 19000, Algérie. \\ (2)Département Mécanique et verre, Institut de Physique de Rennes, UMR UR1- CNRS 6251 \\ Bât. 10B, Campus de Beaulieu, 35042 Rennes cedex, France.
}

E-mail: benbahouche_s@yahoo.fr

\begin{abstract}
:
The response of glass to a scratch experiment is first reviewed. Then the influence of the applied load on the microcracking pattern, the apparent friction coefficient, and the strength (post scratch test) are studied and discussed for a soda-lime-silica glass (standard window glass composition). As the normal load increases, the depth of the radial crack seems to stabilize at about $100 \mu \mathrm{m}$ length. Correlatively its is observed that the residual strength of the scratched glass remains at about $40 \mathrm{MPa}$ whatever the scratch load above $0.5 \mathrm{~N}$. Generally, this work contributes theoretically in the understanding of the existing factor controlling scratch in glasses.
\end{abstract}

Keywords: Scratch, median crack, lateral crack, strength, glass.

\section{Introduction}

Contact between a solid particle and a surface of a brittle material is fundamentally interesting to understand the formation and the propagation of cracks as well as the deterioration in general on the ceramics and glasses surface exposed to the different exterior attacks either by by erosion, abrasion corrosion or by scratching. It also constitutes a basic method to estimate the hardness of an indentation or scratching and the resistance to rupture of brittle materials.

Glass is a material particularly sensitive to surface damage which can occur when objects are formed, handled or used. Among all the surface damage features, the radial/median cracks have a direct influence on the mechanical strength while the lateral cracks are detrimental to the optical properties (transmission or reflection). Scratching is then of paramount interest because it affects the strength [1]. Knowing the scratch shape permits correlating the response of the material, under controlled contact solicitations, to the physical mechanisms that govern the nature of the damage [2-9].

When performing the scratch test, controlling the contact loading history is necessary because scratches are not only plastic deformation but also cracking, a phenomenon sensitive to the environment [10] and the stiffness of the scratching device [11]. 
Along a scratch performed under a monotonous increasing load on the glass, three different damage regimes are typically observed [3-5] (Fig. 1):

1) Micro ductile regime I (permanent track without visible damage).

2) Micro-cracking regime II, presence of lateral cracks reaching the surface - chips or flakes, and curved radial cracks - chevron.

3) Micro abrasive regime III (presence of much debris and eventually of small emerging lateral cracks).

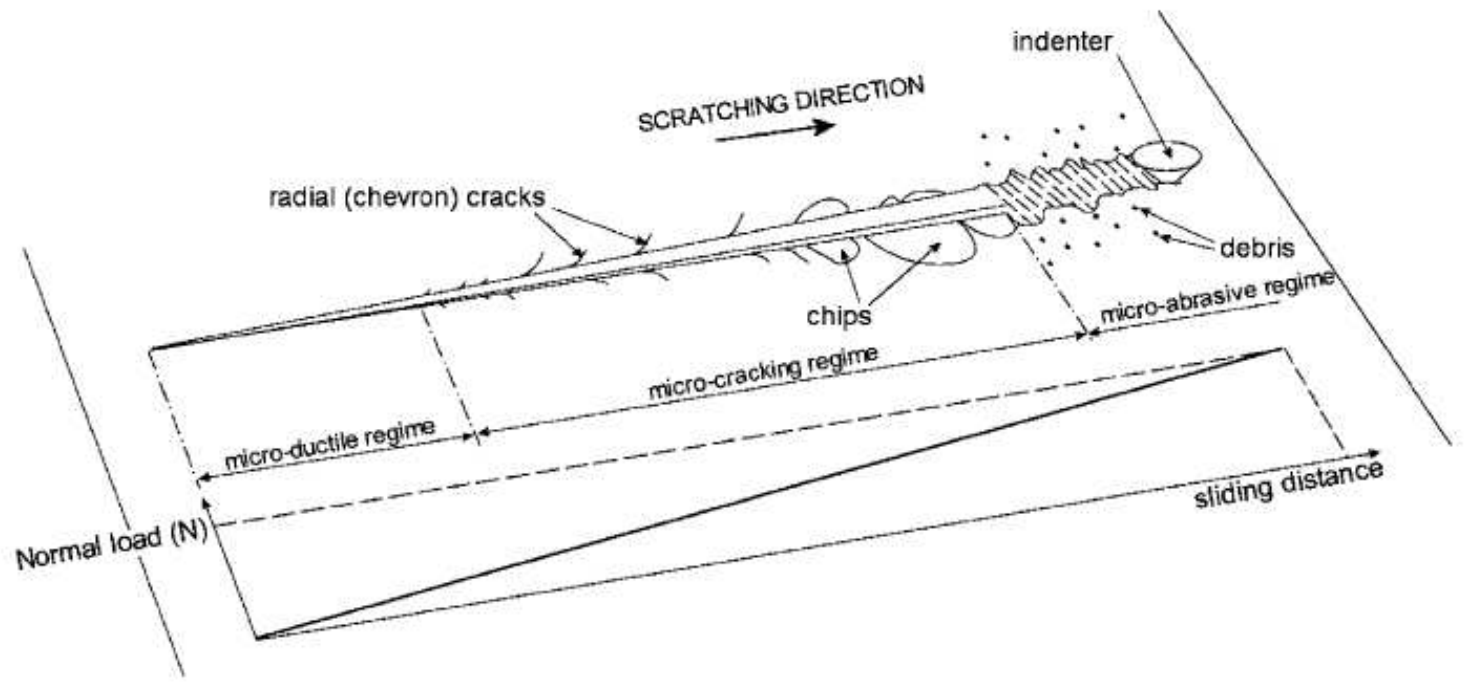

Fig. 1: Typical scratch obtained on a soda-lime-silica glass. [3]

\section{Experimental Procedure}

The glass used in this study was a soda-lime-silica float glass manufactured by ENAVA (Entreprise Nationale du Verre et Abrasifs, Algeria). Samples were square-shaped, $30 \times 30 \times 4 \mathrm{~mm}^{3}$, cut from the same plate.

The chemical composition given by ENAVA is in table 1 .

\begin{tabular}{|l|l|l|l|l|l|l|l|l|}
\hline Oxides & $\mathrm{SiO}_{2}$ & $\mathrm{Na}_{2} \mathrm{O}$ & $\mathrm{CaO}$ & $\mathrm{MgO}$ & $\mathrm{Al}_{2} \mathrm{O}_{3}$ & $\mathrm{~K}_{2} \mathrm{O}$ & $\mathrm{SO}_{3}$ & Balance \\
\hline Wt (\%) & 71.5 & 1.77 & 8.33 & 3.97 & 13.2 & 0.83 & 0.69 & 0.20 \\
\hline
\end{tabular}

Table 1: Chemical composition of the glass.

Young's modulus $(E)$ : $72 \mathrm{GPa}$, Poisson's ratio $(v)$ : 0.22 and hardness $(H v): 6.55 \mathrm{GPa}$ were measured respectively by ultrasonic pulse echo technique and macro indentation.[12] Samples were scratched with a laboratory homemade linear sclerometer, designed to permit loading and scratch velocity to be controlled during the test. The tangential and the normal 
forces were recorded during the test [3]. The indenter was a Vickers diamond type, leading edge oriented.

The scratches were made under different normal loads $(W): 0.1 ; 0.3 ; 0.5 ; 0.7 ; 1.0 ; 1.5 ; 2.0 \mathrm{~N}$ $( \pm 0.01 \mathrm{~N})$, with a constant scratching velocity of $(10 \pm 1) \mu \mathrm{m} / \mathrm{s}$.

The loading path was composed of a ramp followed by a plateau (Fig. 2).

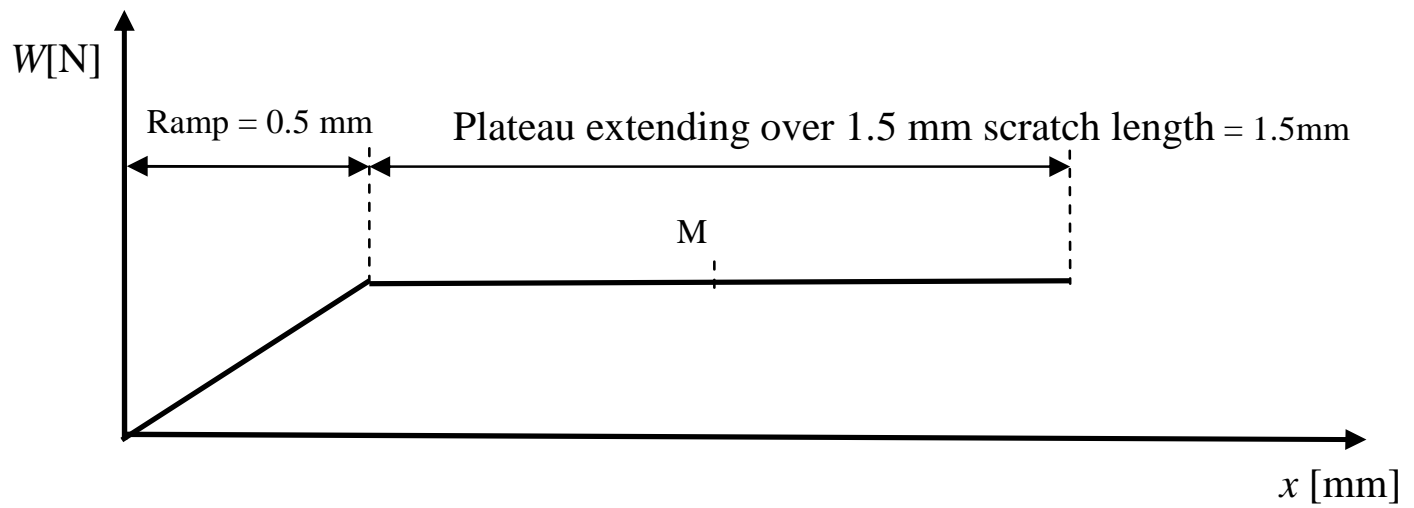

Fig. 2: Loading path consisting of a ramp and a constant-load plateau

Just after scratching, top view microscopic observations have been done using a microscope $2 \mathrm{D}$ and bending tests were performed on specimens to determine strength, with a three points bending device mounted on a LLOYD LR 50K compression testing machine (Fig.3). The scratch was positioned under the upper loading point so as to have the maximum opening tensile stress perpendicular to the scratch [1]. The median crack length was measured at the origin of the rupture, on the fractured surface after the strength test.

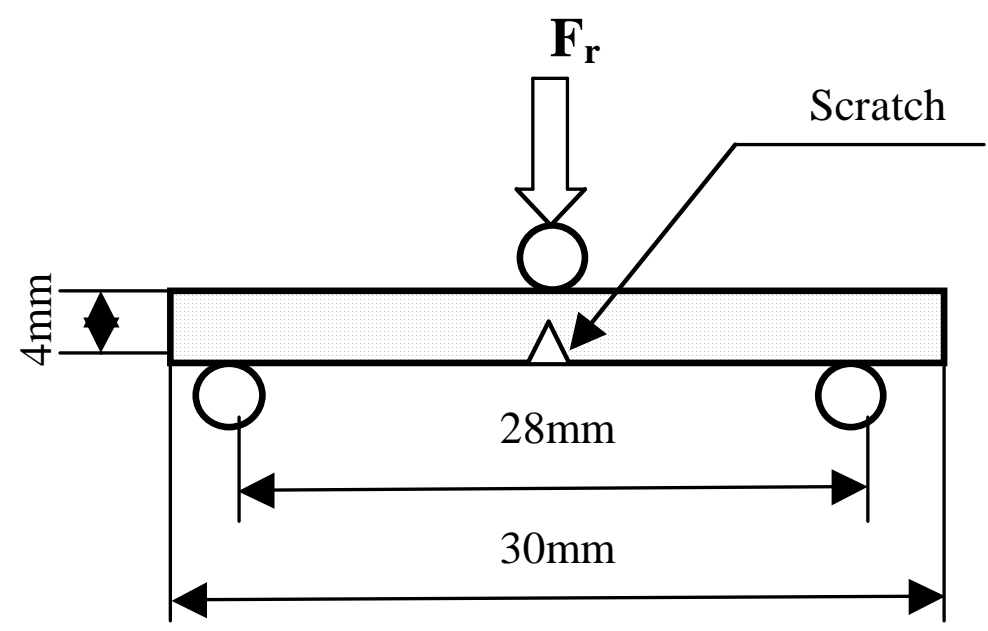

Fig. 3: Three-points bending test. 
The monotonous loading rate three-points bending test is carried out according to the instructions of the NFT57-105 standard, then the mechanical strength $\sigma_{\mathrm{r}}$ has been calculated using [7], [13].

$$
\sigma_{\mathbf{r}}=\frac{3 F_{Y} l}{2 b a^{2}}
$$

With $F_{r}$ is the fracture load, $l$ the distance between the two lower supports ( $\left.28 \mathrm{~mm}\right), b$ the width of the sample (measured for each sample) and $a$ the thickness of the sample (4 mm).

\section{Results and discussion}

The top view optical observations of scratches obtained for each condition are gathered in table 2. A schematic representation of the subsurface crack pattern has been drawn for each scratch. 


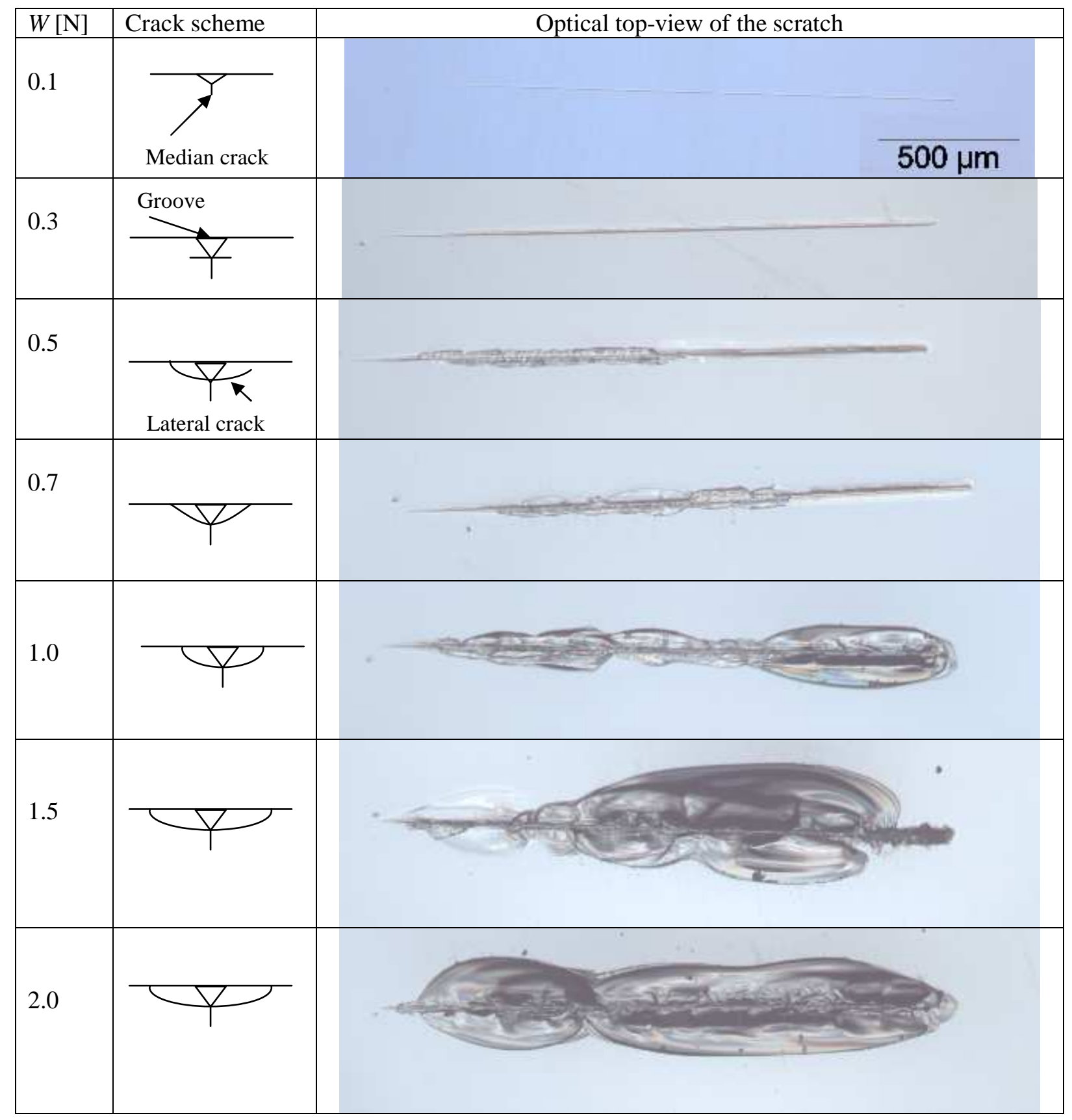

Table 2: Optical top-view of scratches for the different loads $(0.1 ; 0.3 ; 0.5 ; 0.7 ; 1.0 ; 1.5 ; 2.0 \mathrm{~N})$ at a constant velocity $V=10 \mu \mathrm{m} / \mathrm{s}$.

We can observe that for $0.1 \mathrm{~N}$, there is only the birth of the median crack, and from $0.3 \mathrm{~N}$ until $0.7 \mathrm{~N}$, lateral cracks initiate and propagate inside the material without intersecting the surface. Beyond $1 \mathrm{~N}$ until $2 \mathrm{~N}$ lateral cracks are intersecting the surface and result in chips growing while increasing the load. The micro abrasive phenomena is occurring at the end of 
the scratch due to the plowing of the indenter with glass debris (chips and fragments) when scratching.

Increasing the load $(W)$ modifies the cracking system and develops the elasto-plastic deformation, which causes an increase in the tangential force $(F t)$. The apparent friction coefficient $\mu_{0}$, ratio between $F_{t}$ and $W$, allows for a better understanding of the influence of all these effects when plotting versus the normal load $W$ (Fig. 4).

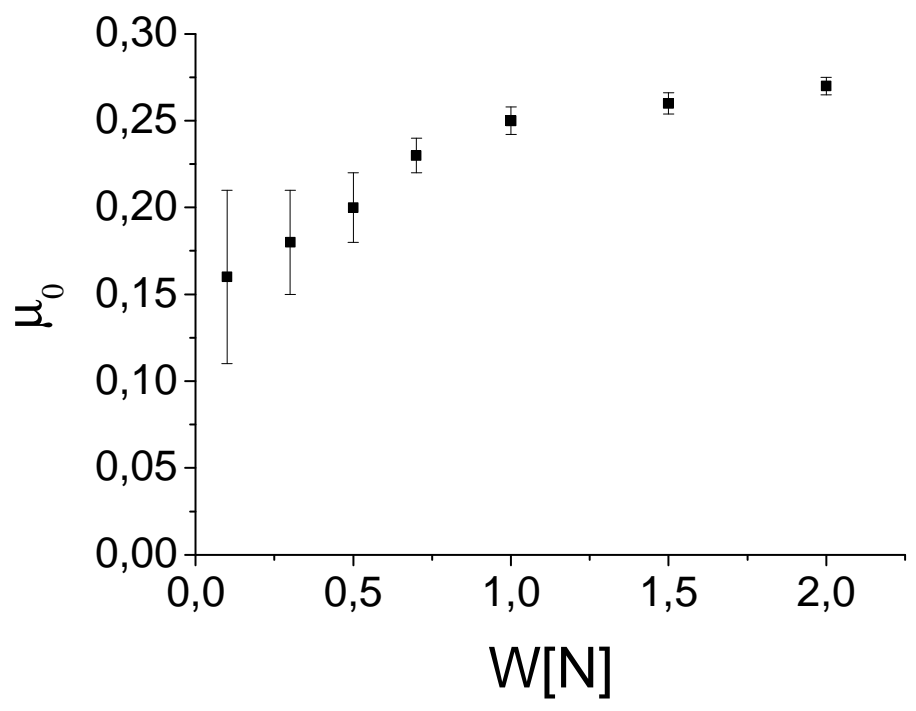

Fig. 4: Effect of normal load on the friction coefficient $\left(\mu_{0}\right)$.

The apparent friction coefficient increases almost linearly until $\mathrm{W}$ reaches $0.7 \mathrm{~N}$ and then stabilizes for $\mathrm{W}$ around $2 \mathrm{~N}$. In the case of scratching of glass, we consider that the tangential effort, $\left(F_{t}\right)$ should be divided as follows: a ductile deformation effort $\left(F_{d e f}\right)$, a coulombian friction effort $\left(F_{f}\right)$ and a cracking effort $\left(F_{c r}\right): F_{t}=F_{\text {def }}+F_{f}+F_{o r}$.

Thus $\mu_{0}=\frac{F_{t}}{W}=\frac{F_{\text {def }}+F_{f}+F_{c r}}{W}=\mu_{d e f}+\mu_{f}+\mu_{c r}$

With $\mu_{\text {def }}=\tan (\beta)=$ constant (considering a pure plastic deformation, where $\beta$ : is the rake angle), $\mu_{f}=\frac{F_{f}}{W}=$ constant (considering a Coulombian friction).

Extrapolating $\mu_{0}$ to $W=0$ allows measuring the Coulombian friction coefficient $\mu_{f}=0.16$, a key parameter when trying to model and simulate scratching experiment by means of numerical methods.

When $W>0$, assuming that $\mu_{\text {def }}$ and $\mu_{f}$ are constant, the increase of the apparent friction coefficient $\mu_{0}$ in the range $[0.1-0.7 \mathrm{~N}]$ is due to the cracking effort $F_{c r}$ which rises as the 
median crack. Above $1 \mathrm{~N}$ the cracking effort $F_{c r}$ becomes more stable due to the occurrence of the lateral cracking acting as a lever on rear side of the indenter.

Focusing on the cracking phenomena, the depth of the median crack $p_{\text {crack }}$ increases rapidly for loads ranging from 0.1 to $0.7 \mathrm{~N}$, the upper bound to represent the median to lateral crack transition (Fig. 5).

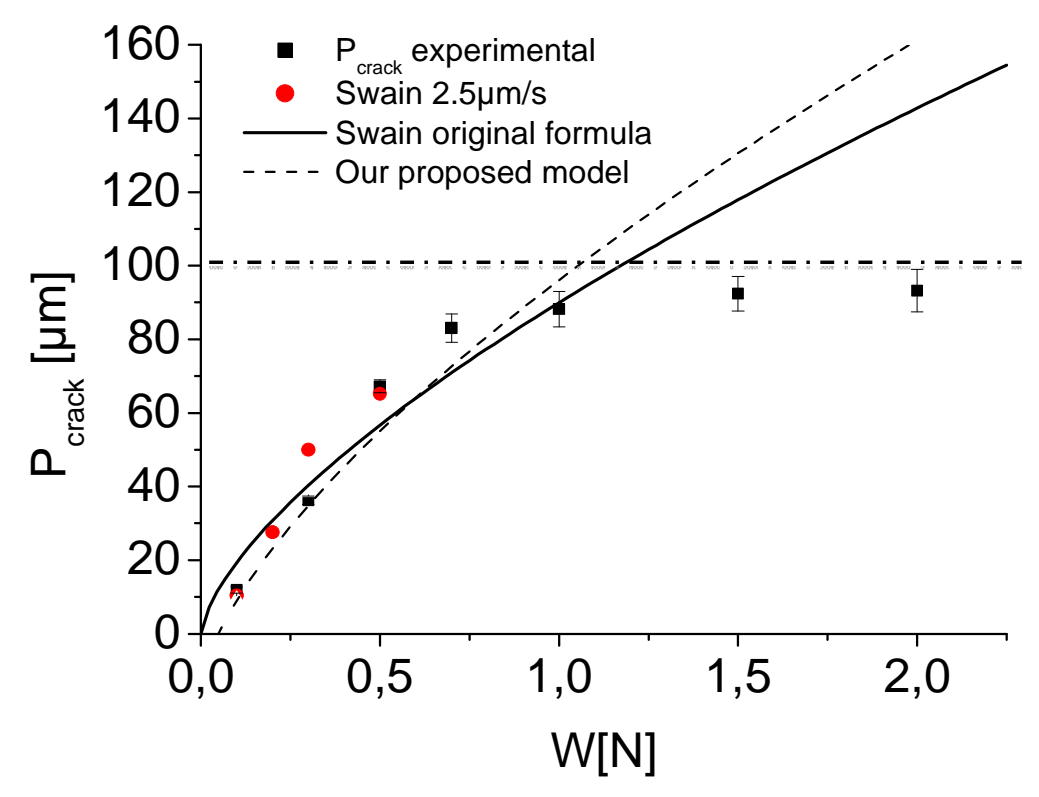

Fig. 5: Effect of the normal load on the median crack depth.

To model the increase of the median crack depth $p_{\text {crack }}$ as a function of applied normal load $W$, one can use the model proposed by Swain [14-15]:

$$
p_{\text {crack }}=\frac{1}{\pi}\left(\frac{m_{e} \sqrt{1+\mu^{2}}}{K_{c} \tan \psi}\right)^{2 / 3} W^{2 / 3}
$$

Where $\mu$ is the Coulombian friction coefficient, $K_{c}$ the toughness, $\psi$ the half-angle at the vertex of the indenter and $\mathrm{m}_{\mathrm{e}}$ a modifying factor that takes into account slight differences in crack shape from that considered by Lawn and Fuller [15] and also allows for the increased indentation pressure.

The comparisons of Swain's experimental results obtained for a scratching velocity of $2.5 \mu \mathrm{m} / \mathrm{s}$ with ours show a good agreement even if the scratching speed is a little bit different. When fitting all the data with Swain original formula, one found that the value of the constant $m_{e}$ is equal to 8 instead of 4 as proposed in Swain's original publication. 
Swain's model is not taking into account a cracking threshold. Reporting the crack depth as a function of the normal load on a graph $p_{\text {crack }}=f\left(W^{2 / 3}\right)$, allows for an estimation of this threshold (Fig. 6).

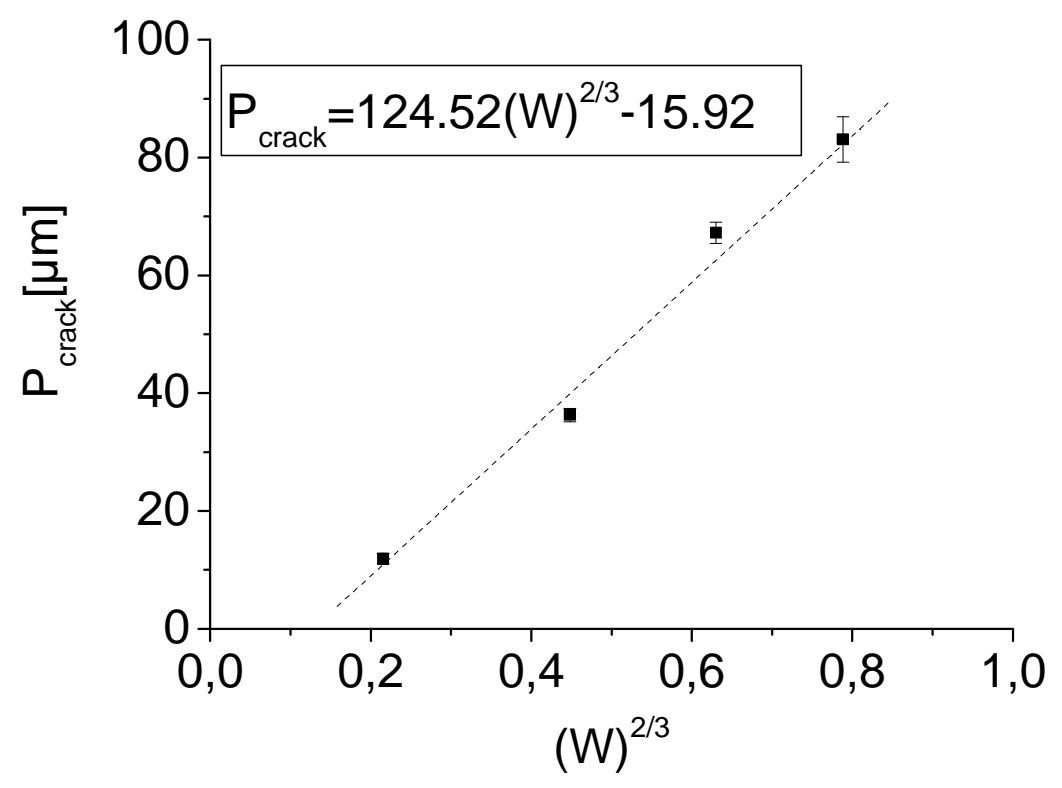

Fig. 6: Effect of normal load for [0.1-0.7 N] on the median crack depth.

The $2 / 3$ power law is in good agreement with the median crack length evolution. A $W_{0}=0.046 \mathrm{~N}$ load, below which there is no cracks $p_{\text {crack }}=0$, confirms the existence a threshold.

So, the model in accordance with the experimental results in the range $[0.1-0.7 \mathrm{~N}]$ that we proposed is:

$$
p_{\text {crack }}=\frac{1}{\pi}\left(\frac{m_{e}}{K_{c} \tan \psi}\right)^{2 / 3} \sqrt[3]{\left(1+\mu_{f}^{2}\right)}\left(W-W_{0}\right)^{2 / 3}
$$

Where $W_{0}$ is the threshold load.

Reporting the mechanical strength $\sigma_{\mathrm{r}}$, versus the applied load $W$ below or equal to $1 \mathrm{~N}$ (Fig.7), allows saying that one have a good agreement with the theory of the fracture mechanics, meaning that the mechanical strength decreases with the increase of the flaw size created on the surface. 


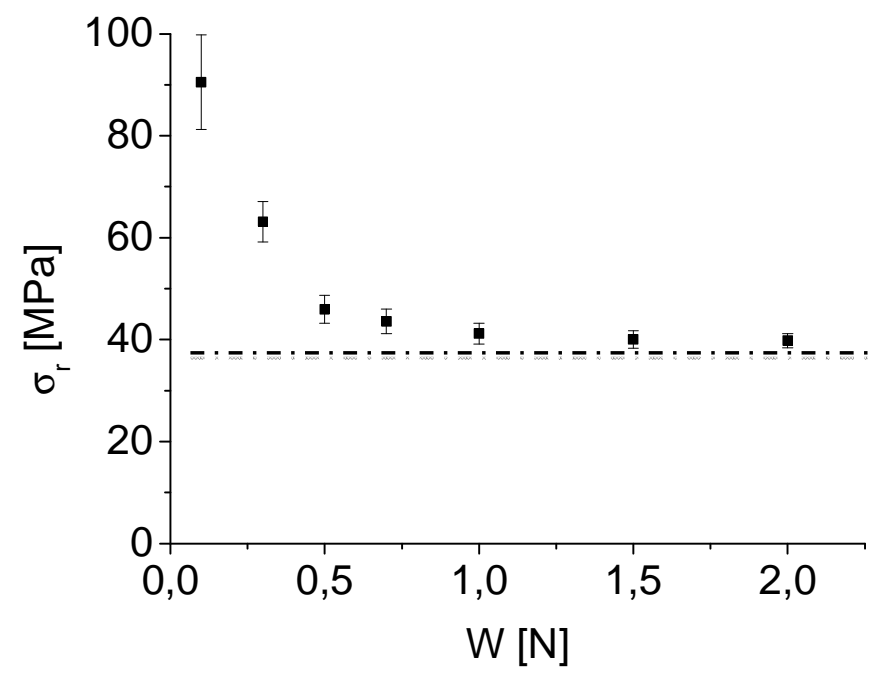

Fig. 7: Effect of normal load on the mechanical strength $\left(\sigma_{\mathrm{r}}\right)$.

The mechanical strength tends to stabilize near $40 \mathrm{MPa}$ for a load larger than $1 \mathrm{~N}$. This confirms the saturation of the median crack length $\left(p_{\text {crack }}\right)$ (see Fig. 5). $\sigma_{r}$ is clearly controlled by the deepest crack that is the median crack for the case of scratching.

As a consequence, the optimal load to ensure the good cut of a piece of glass, without any lateral cracks, i.e. with clear edges, is $W=1$ N. However, in Swain [14] or Cheng [16] papers, one can deduce that to have a good cut of the glass it's necessary to increase the load to a certain level (see Fig. 5).

The determination of the mechanical strength by three points bending allows characterizing the crack responsible for this rupture that is the median crack. One can consider this surface crack as a semi elliptic one submitted to a tensile stress (see Fig. 8).

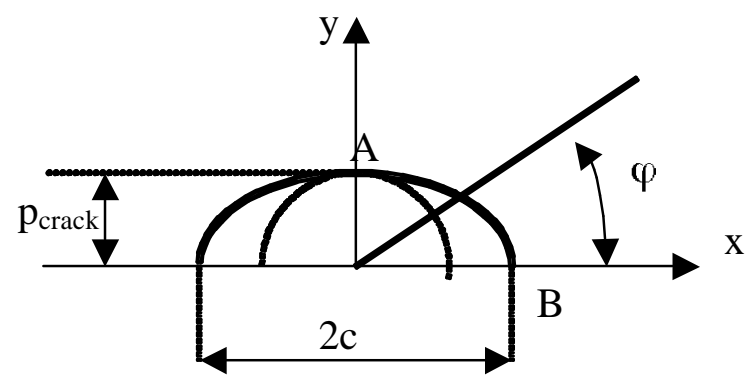

Fig. 8: Semielliptical crack geometry.

The stress intensity factor $K_{c}$ can be expressed as [17-19]:

$$
K=\sigma \frac{M}{\phi} \sqrt{\pi p_{\text {rack }}}
$$


Where $\sigma$ is the fracture stress, $p_{\text {crack }}$ is the crack length, $M$ is a correction factor depending on the position of the crack initiation site (in our case the point A), and M takes the value of 1,14 [17-19]. $\phi$ is an elliptic integral that depends on the ratio $p_{c r a c k} / c$ (where $2 c$ is the scratch length in our case):

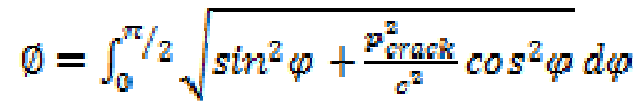

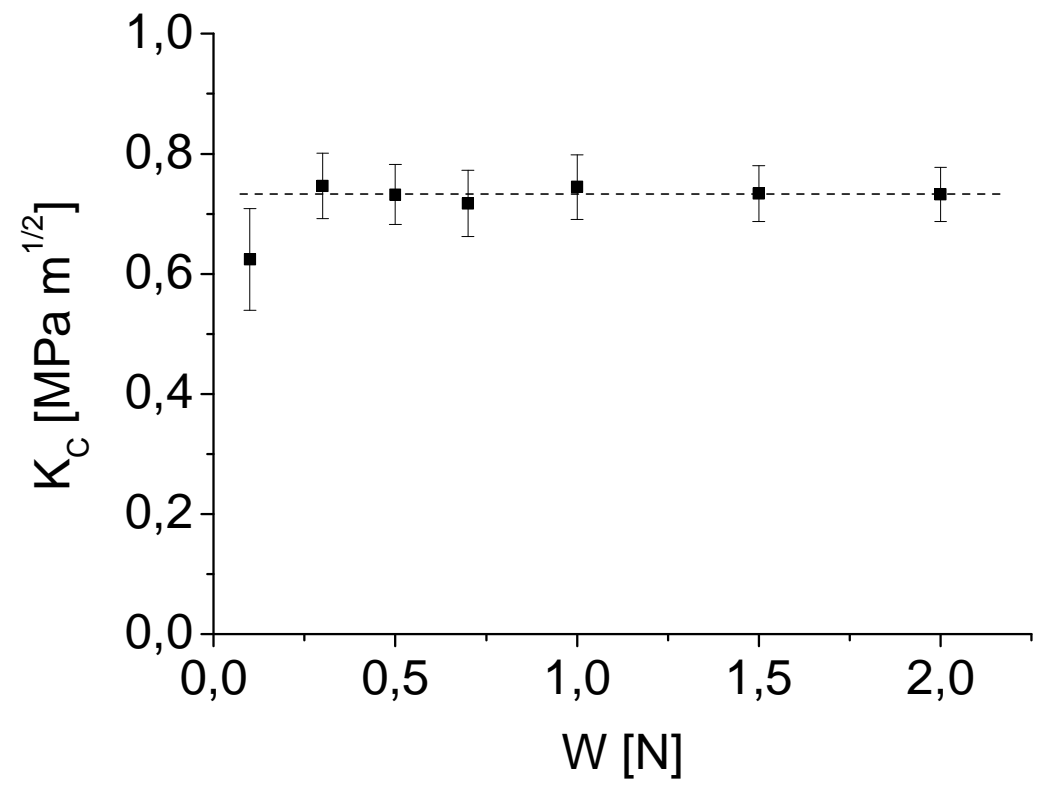

Fig. 9: Fracture toughness as a function of the normal load for scratching.

Measuring the crack length allows to estimate the toughness of the glass from Equations (4 and 5). A value of $0.73 \mathrm{MPa}^{1 / 2}$ is, in good accordance with the value determined experimentally by a $2.492 \mathrm{~N}$ indentation (Fig. 9). One can notice that the toughness is almost constant, considering the measuring uncertainties, for loads ranging from 0.3 to $2 \mathrm{~N}$. Considering the value of the toughness obtained for $0.1 \mathrm{~N}$, one have a value $15 \%$ below the mean ones. This should be due to the fact that one has some low residual stresses on the surface which should influence the propagation of very short cracks.

\section{Conclusion}

In this study we tried to simulate two phenomena: one is the machining (carving) of the glass by scratching and the other conditions of aggressions caused by the bad manipulations. These lead to scratches on the soda-lime glass surface (under controlled conditions of the laboratory) in order to understand the nature of the damage, the system of cracking and the 
role of one of the scratching parameters which is the load on the evolution of the deterioration.

Our work is essentially based on the influence of the applied load on geometric parameters of the scratch, the median crack, friction coefficient and their consequences on the mechanical strength as well as the toughness of soda-lime glass.

On the basis of the obtained experimental results, we can conclude that:

- The deformation level becomes more and more important while increasing the load $(W)$.

- The friction coefficient increases with the increase of the load until $1 \mathrm{~N}$ then beyond this load it stabilizes.

- The coefficient corresponding to a pure friction $\mu_{a d}=0.156$.

- The growth of the friction coefficient $\left(\mu_{0}\right)$ for the interval of load $[0.1-1 \mathrm{~N}]$ is caused by the increase of the cracking effort. Beyond the load of $1 \mathrm{~N}$ until $2 \mathrm{~N}$, this effort $\left(F_{\text {fis }}\right)$ becomes stable.

- While increasing the load from $0.1 \mathrm{~N}$ until $0.7 \mathrm{~N}$, the depth of median crack $\left(p_{\text {crack }}\right)$ increase, which generates the reduction of the mechanical strength $\left(\sigma_{\mathrm{r}}\right)$.

- Load $0.7 \mathrm{~N}$ represents the radial/ lateral transition load.

- For loads from 0.1 until $0.7 \mathrm{~N}$, the evolution of the median crack has tendency curve $p_{\text {crack }}=124,52 W^{2 / 3}-15,92$.

- The load line of cracking where we don't have a median crack $\left(p_{\text {crack }}=0\right)$ is $W_{0}=0.046 \mathrm{~N}$.

- From the load of $1 \mathrm{~N}$ until $2 \mathrm{~N}$ we have a mutual stabilization of the mechanical strength $\left(\sigma_{\mathrm{r}}\right)$ and of a median crack.

- The optimal load to insure a good cut (machining) of a glass is $W=1 \mathrm{~N}$.

- For loads from 0.3 until $2 \mathrm{~N}$ the toughness is almost constant $K_{c} \approx 0.73$, but it is weaker $K_{c} \approx 0.62$ for the load of $0.1 \mathrm{~N}$.

- For the weak load $0.1 \mathrm{~N}$ we have an elastic-plastic deformation. But for the other loads $(W>0.1 \mathrm{~N})$ the deformation is purely plastic.

This study offers an additional contribution to understanding and prediction of the soda- lime glass cracking, from the process of scratching, if it is submitted to very definite aggression conditions and their influences on one of the most important mechanical properties which is the mechanical strength. Finally, we consider that this work is complementary to the works of Swain [14] and Weili Cheng [16]. 


\section{References}

[1] E. B. Shand «Strength of glass - the Griffith method revised», Journal of American Ceramic Society, 48 [1] (1965)43-49.

[2] T. Rouxel, «Indentation et rayage du verre », Colloque de Sciences des Matériaux, Ecole Polytechnique Fédérale de Lausanne, 25 Mars, 2003.

[3] V. Le Houérou, J.-C. Sangleboeuf, S. Dériano, T. Rouxel, G. Duisit, « Surface damage of soda-lime-silica glasses : indentation scratch behavior », Journal of Non-Crystalline solids, 316 (2003) 54-63.

[4] T. Rouxel, N. Dély, J. C. Sangleboeuf, «Structure-property correlations in Y-Ca-MgSialon Glasses: physical and mechanical properties», Journal of American Ceramic Society, 88 [4] 889-896, 2005.

[5] S. Dériano, A. Truyol, J. C. Sangleboeuf, T. Rouxel, « Physical and mechanical properties of a new borosilicate glass», Ann. Chim. Sci. Mat. 28 (2003) 55-62.

[6] A. Djamai, K.-J. Chin, H. Zaidi, "Formation et propagation des fissures dans les matériaux fragiles lors d'un rayage ou d'une indentation par indenteur sphérique », $\mathrm{XVI}^{\mathrm{e}}$ Congrès Français de Mécanique, Nice 1-5 Septembre 2003.

[7] S. Benbahouche, F. Roumili, R. Zegadi, « Mechanical strength of tempered soda-lime glass damaged by sand gravitation, determined by bending with circular supports », Glass Technology, Volume43C, (2002) 286-289.

[8] S. Benbahouche, F. Roumili, R. Zegadi, «Effect of water on the impact strength of glass plates with eroded surfaces », Materials Science Vol.39 N¹, (2003) 148-152.

[9] S. Benbahouche, F. Roumili, A. Seghir, R. Zegadi, «Effect of water on the transmittance of glass plates with eroded surfaces», Journal of the European Ceramic Society, 26, (2006) 1673-1678.

[10] S. Fünfschilling, T. Fett, M. J. Hoffmann, R. Oberacker, G. A. Schneider, P. F. Becher, J.J. Kruzic, "Crack-tip toughness from Vickers crack tip opening displacements for materials with strongly rising R-curves", Journal of the American Ceramic Society, 2011, 94 (6) 18841892.

[11] K Li, Y Shapiro, J.C.M Li , « Scratch test of soda-lime glass», Acta Materialia, Vol. 46, Issue 15, (1998)5569-5578.

[12] J-P Guin, T. Rouxel, J-C Sangleboeuf "Hardness, toughness and scratchability of germanium-selenium chalcogenide glasses", Journal of American Ceramic Society, 85 [6] (2002)1545-1552.

[13] J. Zarzycki, Le Verre et L'État Vitreux, Edition Masson, Paris (1982).

[14] M. V. Swain « Micro fracture about scratches in brittle solids», Proc. R. Soc. Lond. A. 366, (1979) 575-597. 
[15] Lawn B. R. and Fuller E. R. "Equilibrium penny-like cracks in indentation fracture", Journal of Materials science, Vol. 10, (1975), 2016-2024.

[16] Weili Cheng, E. Ling, L. Finnie « Median cracking of brittle solids due to scribing with sharp indenters », Journal of American Ceramic Society, 73 (3), (1990) 580-586.

[17] John J. Petrovic «Effect of indenter geometry on controlled-surface-flaw fracture toughness», Journal of American Ceramic Society, 66 [4] 277-283, 1983.

[18] S. Dériano, A. Jarry, T. Rouxel, J. C. Sangleboeuf, S. Hampshire , « The indentation fracture toughness $(\mathrm{Kc})$ and its parameters: the case of silica-rich glasses», Journal of NonCrystalline solids, 344 (2004) 44-50.

[19] J. J. Kruzic and R. O. Ritchie, «Determining the toughness of ceramics from Vickers indentations using the crack-opening displacements: An experimental study», Journal of American Ceramic Society, 86 (8), (2003) 1433-1436. 